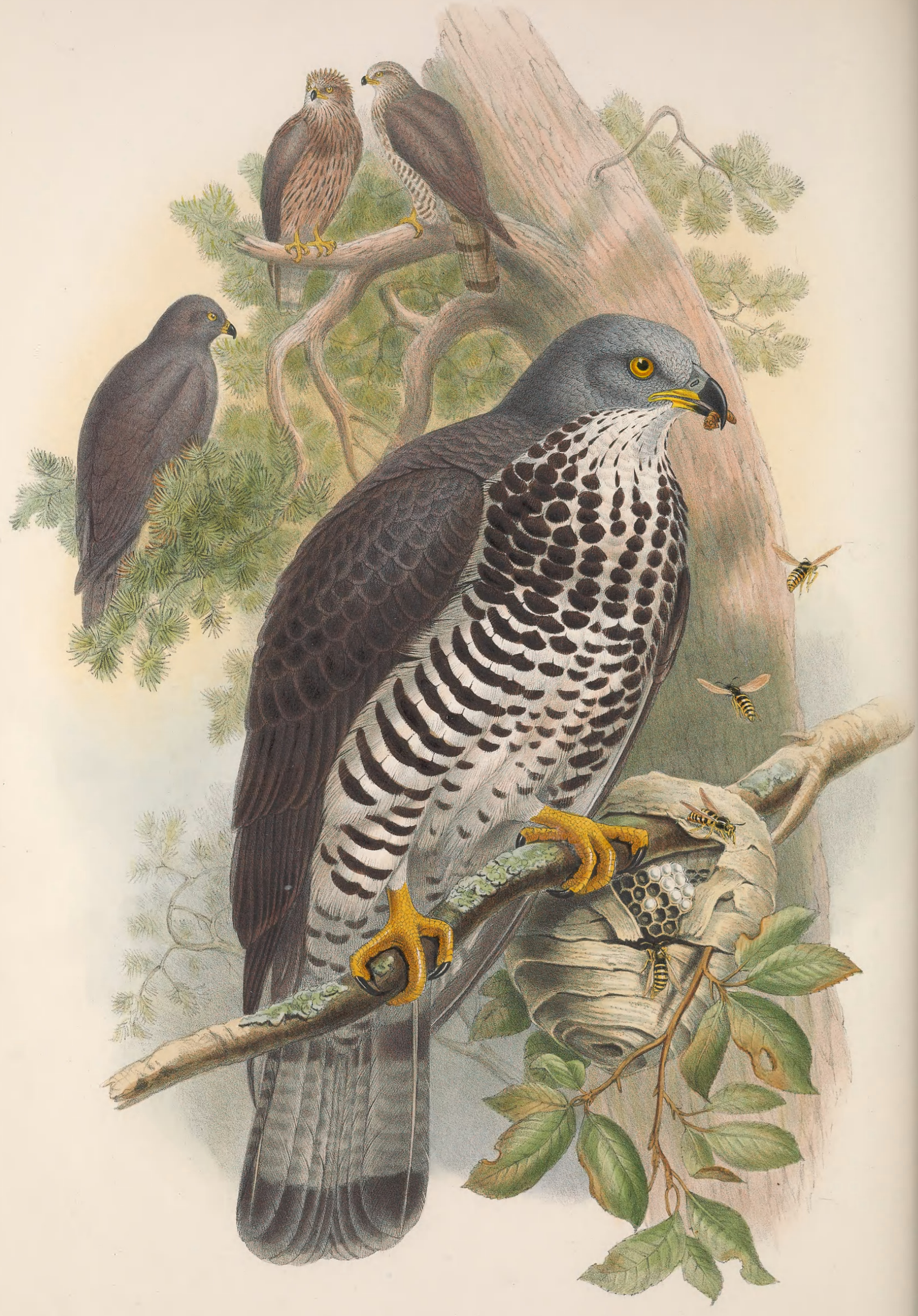

PERNIS APIVORUS. 


\title{
PERNIS APIVORUS.
}

\section{Honey-Buzzard.}

\author{
Falco apivorus, Linn. Faun. Suec., p. 23. \\ Pernis apivorus, Cuv. Règn. Anim., 1817, tom. i. p. 323. \\ Falco poliorhynchus, Bechst. Taschenb. Deutschl, Vög., tom. i. p. 19. \\ — dubius, Sparrm. Mus. Carls., tab. 26. \\ incertus, Lath. Ind. Orn., vol. i. p. 32. \\ Accipiter lacertarius, Pall. Zoog. Ross.-Asiat., tom. i. p. 359. \\ Pernis apium, Brehm, Vög. Deutschl., tom. i. \\ - vesparum, Brehm, ib. p. 47, tab. 4. fig. 3. \\ - apivora, Macgill. Hist. Brit. Birds, vol. iii. p. 254. \\ Buteo apivorus, Vieill.-Nouv. Dict. d'Hist. Nat., tom. iv. p. 479.
}

THE diversities of form which exist in every great group of birds, are always accompanied by a difference in habits, manners, and economy. Among the Falconidæ many variations of this kind occur, some very marked, others but slightly indicated: thus the aerial Eagles with their ample wings and feathered legs generally prey upon living quadrupeds; the Sea-Eagles, distinguished by their scaly tarsi and more lengthened bills, occasionally appease their appetites with carrion; the swift-flying Falcons, remarkable for their great muscular power and length of wing, seize Mallards, Grouse, and other birds of like size ; the insect-loving Kestrels are characterized by the feebleness of their feet and claws, and the snake-devouring Harriers by their lengthened legs. These remarks might be greatly extended, were it desirable so to do. Perhaps no circumstance connected with the Falconidæ is more remarkable than that we should find among their number a species which is in the habit of feeding on the larvæ of wasps and humblebees: yet this is really the case ; for we have abundant evidence that the predatory bird represented on the opposite Plate descends to the ground and digs out the nests of those insects, notwithstanding the thousands of darts which must be hurled against this enemy of their domain and destroyer of their progeny. Of this particular Cuckoo-like form, the genus Pernis, there are two species, one inhabiting Europe, the other India. They both have the same habits and manners; both are natives of warm rather than cold regions; and their peculiar food being only obtainable during the summer months, it is at that season alone that the HoneyBuzzard is to be met with in this country. The bird, however, is not confined to one kind of diet; for it passes much of its time on the ground among the herbage in capturing insects of many kinds and forms, from the locust to the grass-loving moth; it will also eat frogs, snakes, and other reptiles, young birds, their eggs, and small quadrupeds if they fall in its way.

It gives me great pleasure to state that the Honey-Buzzard appears to have become much more common in England of late than it was formerly. The Kites, the Harriers, and the Buzzards are almost all gone, probably never to return; but every spring, numbers of this species visit many parts of the south of England, almost a hundred instances of its capture in the New Forest, Wales, Norfolk, and other parts of the country being on record. This being the case, it is to be hoped that the bird will meet with some degree of protection : it is, however, but a forlorn hope, I fear ; for if the old birds escape the wariness of the gamekeeper, to whom they do no harm whatever, their nest will be robbed of its beautiful eggs to supply the demands of collectors. It would, indeed, be a pleasant sight to see this bird skimming in silent, buoyant, and gliding flight over the inland waters, or soaring above the trees of our few remaining forests. In that of Hampshire the month of May never passes without the Honey-Buzzard forming its eyrie in some lofty tree ; and if it were allowed to remain unmolested and rear its young, a greater number would doubtless return thither the ensuing year to live upon the frogs, newts, snakes, and other animals formerly kept in check by Harriers, Buzzards, \&c., which no longer abide there, to say nothing respecting the great value of its services in lessening the numbers of the insects upon which it habitually feeds.

Since White published his interesting account of the nesting of this bird in Selborne Hanger, it has been observed in all parts of England, and many times captured both in Scotland and in Ireland. Mr. A. Newton, in the 'Ootheca Wolleyana,' mentions instances of its breeding in Lapland, within the Arctic Circle, and a good deal further north than its range had been supposed to extend. It also inhabits France, Germany, Spain, and Italy, from all of which countries, as well as our own, it migrates to North Africa to spend the winter, and there obtains a supply of food which would be denied it in colder regions-frost and snow being inimical to the animals upon which it feeds, and which then retire to their winter quarters.

Much diversity is observable in the colouring of this species; the young, too, differ not only from the 
adult, but also from each other. I have seen an immature example of a uniform chocolate-brown, and others in a costume of mingled buff and brown. The bird evidently becomes whiter as it advances in age; some have delicate grey heads, and flanks beautifully barred with dark brown, while older birds have strongly blotched markings over the whole of the under surface. The fine pair from which my figures were taken, were kindly lent to me for the purpose by John Rocke, Esq. They were trapped near that gentleman's seat, Clungunford Hall, Shropshire, early in June 1865.

Sir William Jardine stated in his address to the Members of the Berwickshire Naturalists' Club, in September 1836, that "The district around Twizell, in Northumberland, appears to be very attractive to this species; for within a few years several specimens have been procured, both in the adult and the immature plumage. One of them was observed to rise from the site of a wasps' nest which it had been attempting. to excavate, and to a certain extent had accomplished the operation. The size of the hole which had been made showed that a much greater power could be employed, and that the bird possessed organs much better fitted to remove the obstacles which generally conceal its prey than a superficial examination of the feet and legs would seem to warrant. A few hours afterwards the task was found to be entirely completed, the comb torn out and cleared of the immature young. A steel trap, baited with the comb, secured the aggressor in the course of the next day, when he returned to review the scene of his previous havoc; and dissection proved that at this time mammalia or birds formed no part of its food."

Mr. Thompson states that the stomach of an example killed in Ireland contained a few of the larvæ and some fragments of perfect coleopterous insects, several whitish-coloured hairy caterpillars, the pupa of a species of butterfly, and also of the six-spot Burnet moth." One examined by White of Selborne contained limbs of frogs and many grey shelless suails. In Mr. Stevenson's 'Birds of Norfolk' it is stated that the stomach of an example killed at Holkham, and of a female taken at Saxmundham, was well filled with young wasps; in a third, killed near Lowestoft, were found the remains of Blackbirds' eggs, and in the throat of a fourth several small fragments of the eggs of the Song-Thrush. Mr. Yarrell was told that one kept in confinement killed and ate rats as well as birds of considerable size. It will therefore be seen that, although wasps and their larvæ form part of its food, its diet is so much varied that it may almost be regarded as omnivorous. Buffon says that in winter, when fat, it is itself very good eating.

In lis remarks upon two small birds in full plumage, shot at Northrepps, near Cromer, on the 25th of August, 1857, Mr. Gurney says, "About 9 o'clock this morning I was riding along a broad green drive which runs through a wood in this place, when a Honey-Buzzard rose from the grass and alighted on a tree at the edge of the wood. I shortly after sent my gamekeeper in pursuit of it, and he succeeded in shooting it near the spot where I saw it. Hearing afterwards that it had been seen flying in company with a second specimen, he returned to the drive and succeeded in shooting that also, very nearly at the same spot where he had procured the first specimen, being guided in his search by loud whistling cries which the bird was making, probably as a call-note to the one which had been previously shot. About two hours later my son, who was passing through the drive, saw a third specimen rise from the ground and alight on a tree, in a similar manner and nearly in the same place as the first. The gamekeeper was again seut in pursuit; but when he succeeded in getting a view of this bird, it had risen so high in the air that it was out of shot, and continued flying at a great height, in an inland direction, till it disappeared. Both specimens that were procured were in full adult dress, and possessed the beautiful grey tinge on the head which always distinguishes the adult examples of this bird. On dissection both of these specimens proved to be male birds. Their stomachs contained the remains of wasps and wasp-grubs."

The nest, which is of a very large size, is placed in the forks of trees, often of the beech; it is shallow in form, and built of sticks, of considerable size, intermingled with twigs with their leaves on, and is lined with leaves and wool. The eggs, which are generally deposited in June, are of a bright orange-brown, largely blotched, sometimes in the middle, at others principally at the larger end, with two shades of rich chestnutbrown; their average length is about two inches, by one inch and three-quarters in breadth.

The principal figure in the accompanying Plate represents an adult male, of the natural size, with a nest of the Tree-Wasp; the reduced figures in the distance, an adult female and two immature birds. 


\section{$2 \mathrm{BHL}$ Biodiversity Heritage Library}

Gould, John. 1873. "Honey-Buzzard, Pernis apivorus [PI. 8]." The birds of Great Britain 1, -. https://doi.org/10.5962/p.323791.

View This Item Online: https://www.biodiversitylibrary.org/item/221495

DOI: https://doi.org/10.5962/p.323791

Permalink: https://www.biodiversitylibrary.org/partpdf/323791

\section{Holding Institution}

Smithsonian Libraries

\section{Sponsored by}

Biodiversity Heritage Library

\section{Copyright \& Reuse}

Copyright Status: Public domain. The BHL considers that this work is no longer under copyright protection.

This document was created from content at the Biodiversity Heritage Library, the world's largest open access digital library for biodiversity literature and archives. Visit BHL at https://www.biodiversitylibrary.org. 